\title{
A novel GATA4 mutation responsible for congenital ventricular septal defects
}

\author{
JUAN WANG $^{1 *}$, MING FANG $^{1 *}$, XING-YUAN LIU ${ }^{3}$, YUAN-FENG XIN ${ }^{2}$, ZHONG-MIN LIU ${ }^{2}$, \\ XIAO-ZHONG CHEN ${ }^{4}$, XIAO-ZHOU WANG ${ }^{4}$, WEI-YI FANG ${ }^{5}, \mathrm{XU} \mathrm{LIU}^{5}$ and YI-QING YANG ${ }^{6}$ \\ Departments of ${ }^{1}$ Cardiology and ${ }^{2}$ Cardiothoracic Surgery, East Hospital, Tongji University School \\ of Medicine; ${ }^{3}$ Department of Pediatrics, Tongji Hospital, Tongji University School of Medicine; \\ Departments of ${ }^{4}$ Cardiac Surgery, ${ }^{5}$ Cardiology and ${ }^{6}$ Cardiovascular Research, Shanghai Chest \\ Hospital, Medical College of Shanghai Jiaotong University, Shanghai, P.R. China
}

Received April 6, 2011; Accepted May 19, 2011

DOI: $10.3892 /$ ijmm.2011.715

\begin{abstract}
Ventricular septal defect (VSD) is the most common type of cardiovascular developmental anomaly and is an important risk factor for the substantially increased morbidity and mortality in newborns. Aggregating evidence implicates genetic defects in the pathogenesis of congenital VSD. However, VSD is genetically heterogeneous and the genetic determinants for VSD in most patients remain to be identified. In this study, the whole coding region of the GATA4 gene, which encodes a zinc-finger transcription factor pivotal to cardiogenesis, was initially sequenced in 210 unrelated patients with VSD. The relatives of the index patient carrying the identified mutation and 200 unrelated ethnically-matched healthy individuals used as controls were subsequently genotyped. The functional effect of the mutant GATA4 was characterized in contrast to its wild-type counterpart using a luciferase reporter assay system. A novel heterozygous GATA4 mutation, p.G296R, was identified in a family with VSD inherited as an autosomal dominant trait. Absent in 200 control individuals, the mutation co-segregated with VSD in the family with $100 \%$ penetrance and was completely conserved evolutionarily across species. Functional analysis displayed that the p.G296R mutation of GATA4 was associated with a decreased transcriptional activity. The findings expand the spectrum of mutations in GATA4 linked to VSD and provide more insight into the molecular mechanism involved in VSD. The results of the present study imply the potential implications in the genetic
\end{abstract}

Correspondence to: Dr Yi-Qing Yang, Department of Cardiovascular Research, Shanghai Chest Hospital, Medical College of Shanghai Jiaotong University, 241 West Huaihai Road, Shanghai 200030, P.R. China

E-mail: yang99yang66@hotmail.com

${ }^{*}$ Contributed equally

Key words: ventricular septal defect, transcription factor, genetics diagnosis and gene-specific therapy of this common malformation in infancy.

\section{Introduction}

Congenital heart defects are the most common developmental abnormality with a prevalence of approximately $1 \%$ in neonates, and are the leading non-infectious cause of infant mortality, accounting for more than $29 \%$ of infants who die from a birth defect (1). Congenital cardiovascular anomalies are clinically classified into at least 18 distinct categories with many additional anatomical variations, of which ventricular septal defects (VSDs) are the most common form. VSDs occur in nearly $50 \%$ of all babies with congenital cardiovascular deformations, and account for $14-16 \%$ of cardiac defects that require an invasive treatment within the first year of life $(1,2)$. Congenital VSDs may occur alone or in combination with other cardiac malformations, such as atrial septal defects, pulmonary artery stenosis or tetralogy of Fallot. Despite other deformities that may accompany VSD, larger VSDs may give rise to cardiac enlargement, congestive heart failure, pulmonary hypertension, Eisenmenger's syndrome, delayed fetal brain development, arrhythmias, and even sudden cardiac death in the absence of surgical or catheter based repair (3-7). Nevertheless, the etiology underlying VSDs in the majority of the patients remains largely unclear $(8,9)$.

Congenital VSDs arise from perturbations of cardiac development during embryogenesis and both environmental and genetic risk factors have been implicated in VSDs (8-10). Growing evidence highlights the key role of several transcription factors, including GATA4, in septogenesis (9). The human GATA4 gene maps to chromosome 8p23.1-p22 and consists of 7 exons, encoding a protein of 442 amino acids (11). It is expressed throughout cardiac morphogenesis and is essential for normal cardiac development (12-17). Hence, GATA4 has been one of the prime candidate genes in identifying the inheritable components for structural congenital cardiovascular defects. Presently, more than 40 mutations of the GATA4 gene have been identified in patients with a variety of congenital heart aberrations including VSDs, atrial septal defects, 
tetralogy of Fallot, endocardial cushion defects, patent ductus arteriosus, pulmonary stenosis, and hypoplastic right ventricle (18-33). Nevertheless, the molecular mechanisms responsible for VSD in most patients remain to be elucidated (18-33).

In this study, the coding exons and exon/intron boundaries of GATA4 were sequenced initially in a cohort of 210 unrelated patients with congenital VSDs and a novel heterozygous GATA4 mutation, p.G296R, was identified in a VSD patient with positive family history. Subsequently, genetic analysis of the family members showed that the mutation co-segregated with VSDs inherited in an autosomal dominant fashion. Functional analysis demonstrated that the p.G296R mutation of GATA4 was associated with a decreased transcriptional activity. These findings expand the spectrum of mutations in GATA4 linked to VSDs and provide more insight into the genetic mechanisms involved in human heart development.

\section{Materials and methods}

Study participants. A cohort of 210 unrelated patients with VSD was identified among the Chinese population. Subjects were evaluated by individual and familial history, review of the medical records, complete physical examination, 12-lead electrocardiogram (ECG) and two-dimensional transthoracic echocardiography with color flow Doppler. All patients had a classic form of VSD, with a defect diameter of $>3 \mathrm{~mm}$ and nearly all patients underwent cardiac catheterization and, if required, cardiac surgery. A total of 200 ethnically matched unrelated healthy individuals, which were derived from the general population, were recruited as controls to screen for the identified mutation in GATA4. Peripheral venous blood specimens from VSD cases and control individuals were prepared. The study protocol was reviewed and approved by the local institutional ethics committee and written informed consent was obtained from all participants or their guardians prior to investigation.

Genetic studies. Genomic DNA from all participants was extracted from blood lymphocytes with the Wizard Genomic DNA Purification kit (Promega). The candidate gene GATA4 was screened initially in 210 unrelated patients with VSD and subsequently genotyping GATA4 in the available relatives of the index patient harboring an identified mutation and the 200 control individuals was conducted. The genomic DNA reference sequence of GATA4 was derived from GenBank (accession no. NC_000008). The primer pairs used to amplify the complete coding region of GATA4 by polymerase chain reaction (PCR) were designed as previously described (33). Polymerase chain reaction (PCR) was carried out using HotStarTaq DNA polymerase (Qiagen) on a PE9700 thermal cycler (Applied Biosystems), with standard conditions and concentrations of reagents. Amplified products were analyzed on $1 \%$ agarose gels stained with ethidium bromide and purified with the QIAquick Gel Extraction kit (Qiagen). Both strands of each PCR product were sequenced with a BigDye ${ }^{\circledR}$ Terminator v3.1 Cycle Sequencing kit (Applied Biosystems) under an ABI PRISM 3130XL DNA Analyzer (Applied Biosystems). The sequencing primers used were the same as previously designed for specific region amplification. The DNA sequences were viewed and analyzed with the DNA
Sequencing Analysis software v5.1 (Applied Biosystems). The variant was validated by re-sequencing an independent PCR-generated amplicon from the subject and met our quality control thresholds with a call rate $>99 \%$.

Multiple sequence alignments. The multiple GATA4 protein sequences across species were aligned using the program MUSCLE (version 3.6, an online program at http://www.ncbi. nlm.nih.gov).

Prediction of the disease-causing potential of a GATA4 sequence variation. The disease-causing potential of a GATA4 sequence variation was predicted automatically by MutationTaster (an online program at http://www.mutationtaster.org), giving a probability for the alteration to be either a causative mutation or a harmless polymorphism. Notably, the P-value used here is the probability of the prediction rather than the probability of error as used in t-test statistics, i.e. a value close to 1 indicates a high 'security' of the prediction.

Plasmids and site-directed mutagenesis. The recombinant expression plasmids pSSRa-GATA4 and atrial natriuretic peptide-luciferase reporter gene, which contains the 2600-bp 5'-flanking region of the atrial natriuretic peptide gene, namely atrial natriuretic peptide (ANP)(-2600)-Luc, were kindly provided by Ichiro Shiojima, Chiba University School of Medicine. The identified mutation was introduced into the wild-type GATA4 using a QuickChange II XL Site-Directed Mutagenesis kit (Stratagene) with a complementary pair of primers. The mutant was sequenced to confirm the desired mutation and to exclude any other sequence variations.

Reporter gene assays. COS-7 cells were cultured in Dulbecco's modified Eagle's Medium supplemented with $10 \%$ fetal calf serum. The ANP(-2600)-Luc reporter construct and an internal control reporter plasmid pGL4.75 (hRluc/ CMV, Promega) were used in transient transfection assays to examine the transcriptional activation function of the GATA4 mutant. COS-7 cells were transfected with $0.2 \mu \mathrm{g}$ of wild-type or mutant pSSRa-GATA4 expression vector, $0.2 \mu \mathrm{g}$ of ANP(-2600)-Luc reporter construct, and $0.04 \mu \mathrm{g}$ of pGL4.75 control reporter vector using the PolyFect Transfection reagent (Qiagen). For co-transfection experiments, $0.1 \mu \mathrm{g}$ of wild-type pSSRa-GATA4, $0.1 \mu \mathrm{g}$ of mutant pSSRa-GATA4, $0.2 \mu \mathrm{g}$ of ANP(-2600)-Luc and $0.04 \mu \mathrm{g}$ of pGL4.75 were used. Firefly luciferase and Renilla luciferase activities were measured with the Dual-Glo luciferase assay system (Promega) $48 \mathrm{~h}$ after transfection. Three independent experiments were performed at minimum for wild-type and mutant GATA4.

Statistics. Data are denoted as the mean \pm SD. Differences between the two groups were compared with the Student's t-test for continuous variables and a 2 -tailed $\mathrm{P}<0.05$ was considered to be statistically significant.

\section{Results}

Characteristics of the study subjects. A cohort of 210 unrelated patients with VSD was registered and clinically evaluated in contrast to a cohort of 200 ethnically matched unrelated 
Table I. Clinical characteristics of the 210 unrelated patients with ventricular septal defects.

Characteristics Number or mean value

Percentage or range

Gender (Male, female)

82,128

2.05

5.61

18

Positive family history

17

146

22

25

Muscular

Isolated VSD

VSD, ASD and PDA

VSD, ASD and DORV

VSD, PDA

VSD and PS

Incidence of arrhythmias

Atrioventricular block

Atrial fibrillation

Treatment

Surgical repair

Percutaneous closure

Follow-up

VSD, ventricular septal defect; ASD, atrial septal defect; PDA, patent ductus arteriosus; DORV, double outlet right ventricle; PS, pulmonary stenosis.

healthy individuals used as controls. None of them had overt traditional risk factors for VSD. The baseline clinical characteristics of the 210 unrelated patients with VSD are summarized in Table I.

GATA4 mutations. Direct sequencing of the coding regions of the GATA4 gene was performed after PCR amplification of genomic DNA from the 210 unrelated VSD patients. A heterozygous substitution of cytosine $(\mathrm{C})$ for guanine $(\mathrm{G})$ in the first nucleotide of codon 296 of the GATA4 gene (c.886G>C), predicting the transition of glycine to arginine at amino acid position 296 (p.G296R), was identified in 1 out of 210 patients. The total population prevalence of GATA4 mutations based on the cohort patients was approximately $0.48 \%$. The sequence chromatogram showing the detected heterozygous GATA4 variation of c.886G $>C$ in comparison to the control sequence is displayed in Fig. 1. The variant was neither detected in the control population nor reported in the SNP database at the website http://www.ncbi.nlm.nih.gov/SNP. Genetic scanning of the relatives of the mutation carrier displayed that the gene variant was present in all affected family members alive, but absent in unaffected family members examined. Analysis of the pedigree demonstrated that the mutation co-segregated
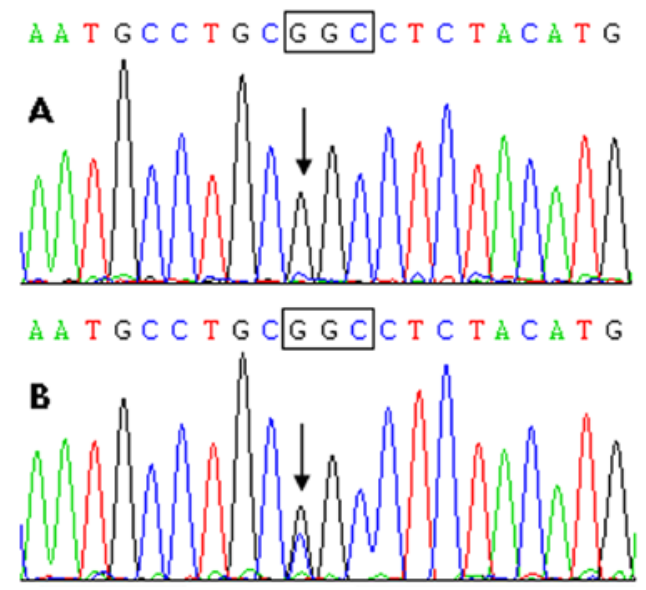

Figure 1. Sequence chromatogram showing the GATA4 mutation identified in family 1 . The arrow indicates the heterozygous nucleotides of $\mathrm{C} / \mathrm{G}$ in the proband from family 1 (B) or the homozygous nucleotides of $\mathrm{G} / \mathrm{G}$ in a control individual (A). The square denotes the nucleotides comprising a codon of GATA4

with VSD transmitted as an autosomal dominant trait in the family with complete penetrance. The pedigree structure of the family is illustrated in Fig. 2. The phenotypic characteristics 
Table II. Phenotypic characteristics and status of the GATA4 mutation in the affected pedigree members.

\begin{tabular}{|c|c|c|c|c|c|c|c|}
\hline \multicolumn{4}{|c|}{ Subject information } & \multicolumn{3}{|c|}{ Phenotype } & \multirow{2}{*}{$\frac{\text { Genotype }}{\text { G296R }}$} \\
\hline Identity & Gender & $\begin{array}{l}\text { Age at time of } \\
\text { study (years) }\end{array}$ & $\begin{array}{l}\text { Age at diagnosis } \\
\text { of VSD (years) }\end{array}$ & $\begin{array}{l}\text { VSD } \\
(\mathrm{mm})\end{array}$ & $\begin{array}{c}\text { Other structural } \\
\text { defects }\end{array}$ & AVB & \\
\hline $\mathrm{I}-1$ & M & $56^{\mathrm{a}}$ & 16 & 20 & ASD, PS & + & N/A \\
\hline II-1 & M & 34 & 9 & 14 & ASD & - & $+/-$ \\
\hline II-6 & $\mathrm{F}$ & 29 & 4 & 11 & - & - & $+/-$ \\
\hline III-2 & $\mathrm{F}$ & 5 & 2 & 12 & - & - & $+/-$ \\
\hline
\end{tabular}

${ }^{\mathrm{a}}$ Age at death. F, female; M, male; VSD, ventricular septal defect; N/A, not available or not applicable; AVB, atrioventricular block; ASD, atrial septal defect; PS, pulmonary stenosis. +, indicates present and -, denotes absent.

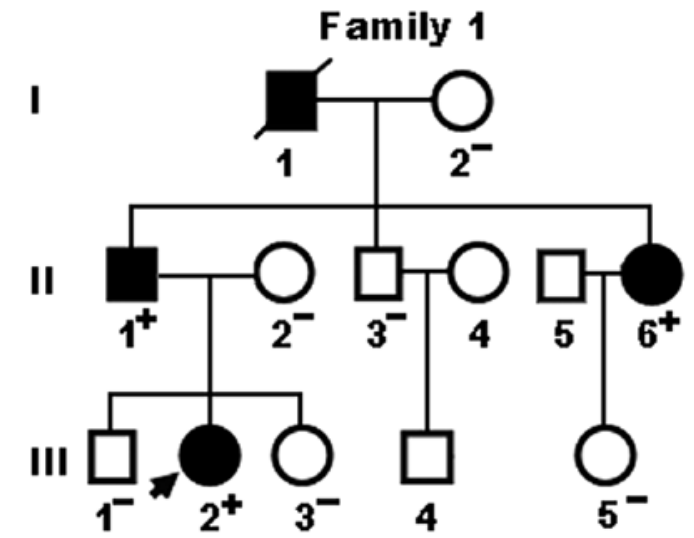

Figure 2. Pedigree structure of the family with a ventricular septal defect. Family members are identified by generations and numbers. Squares indicate male family members; circles, female members; symbols with a slash the deceased members; closed symbols, affected members; open symbols, unaffected members; arrow, proband; +, carriers of the heterozygous mutations; -, non-carriers.

and results of genetic screening of the affected pedigree members are listed in Table II. All the 3 living patients underwent surgical repair of the VSDs.

Multiple alignments of the GATA4 protein sequences across species. A cross-species alignment of GATA4 protein sequences demonstrated that the altered amino acid G296 was completely conserved evolutionarily as shown in Fig. 3, suggesting that the amino acid is functionally important.

Disease-causing potential of a sequence variation. The sequence variation of c. $886 \mathrm{G}>\mathrm{C}$ detected in GATA4 was automatically predicted to be disease-causing with a P-value of 0.99999963 , providing evidence for the alteration to be a malicious disease mutation rather than a benign polymorphism.

Transcriptional activity of the GATA4 mutant. The transcriptional activation function of GATA4 in COS-7 cells was examined using one of its direct cardiac downstream target genes, $A N P$, as a luciferase reporter, and the activity of the $A N P$ promoter was presented as fold-activation of the firefly luciferase relative to the Renilla luciferase. The same amounts of wild-type $(0.2 \mu \mathrm{g})$ and mutant GATA4 $(0.2 \mu \mathrm{g})$ activated the ANP promoter by $\sim 5.5$ - and $\sim 2$.1-fold, respectively. When the same amount of wild-type GATA4 $(0.1 \mu \mathrm{g})$ was cotransfected with mutant GATA4 $(0.1 \mu \mathrm{g})$, the induced activation of the ANP promoter was $\sim 3$.6-fold. These results suggest that mutant GATA4 has significantly reduced activation activity compared with wild-type GATA4 (as shown in Fig. 4).

\section{Discussion}

In the present study, we report a previously unrecognized missense mutation of GATA4 identified in a family with congenital VSD. The novel heterozygous mutation was present in all the affected family members alive but absent in unaffected relatives examined and in the 400 normal chromosomes from a matched control population. A cross-species alignment of GATA4 protein sequences showed that the altered amino acid was completely conserved evolutionarily. Functional analysis displayed that the p.G296R mutation of GATA4 was associated with a significantly decreased transcriptional activity. Therefore, it is very likely that mutated GATA4 is responsible for the VSD in this family.

GATA transcription factors are a family of transcription factors characterized by their ability to bind to the consensus DNA sequence 'GATA'. In vertebrates, six members of the GATA family have been identified, of which GATA4, GATA5 and GATA6 are expressed mainly in the developing heart (34). GATA4 contains 2 transcriptional activation domains (TAD1, amino acids 1-74; TAD2, amino acids 130-177), 2 zinc finger domains (ZF1, amino acids 215-240; ZF2, amino acids 270-294), and 1 nuclear localization signal (NLS, amino acids 295-324) (31). The two TADs are essential for the transcriptional activity of GATA4. The C-terminal ZF1 is required for DNA sequence recognition and binding to the consensus motif, while the N-terminal ZF2 is responsible for sequence specificity and stability of protein-DNA binding. The NLS sequence is associated with the subcellular trafficking and distribution of GATA4 $(31,34)$. The GATA4 G296R mutation identified in this study is located in the NLS, and it thus may influence the transcriptional activity of GATA4 via a failure to target the protein to the cell nucleus through the nuclear pore complex. 


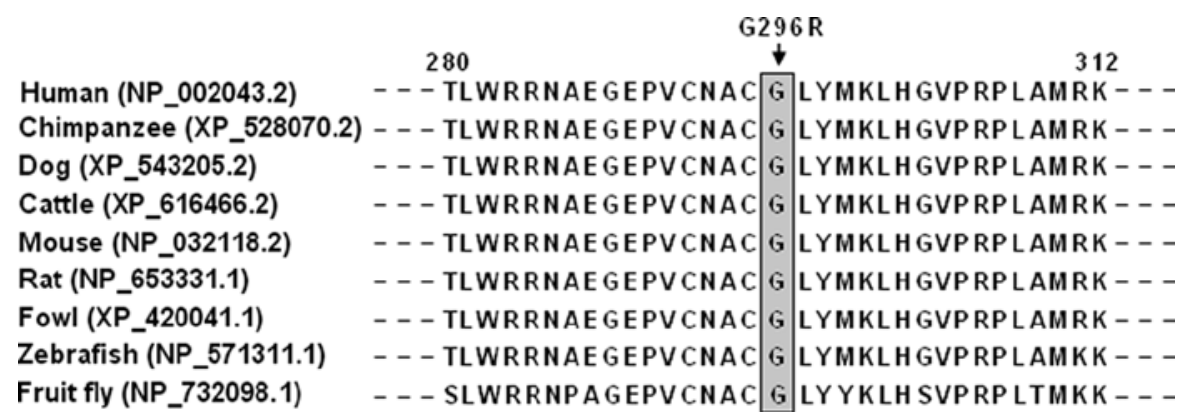

Figure 3. Alignment of multiple NKX2-5 protein sequences across species. The altered amino acid of p.G296 is completely conserved evolutionarily among the examined species.

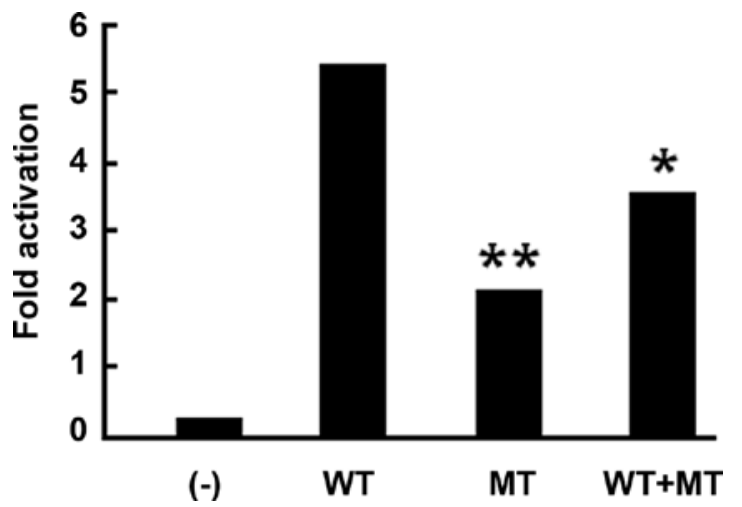

Figure 4. Transcriptional activity of the mutant GATA4 on the ANP promoter COS-7 cells were transfected with $0.2 \mu \mathrm{g}$ of wild-type or mutant pSSRaGATA4 expression vector, $0.2 \mu \mathrm{g}$ of the ANP(-2600)-Luc reporter construct, and $0.04 \mu \mathrm{g}$ of pGL4.75 control reporter vector. For co-transfection experiments, $0.1 \mu \mathrm{g}$ of wild-type pSSRa-GATA $4,0.1 \mu \mathrm{g}$ of mutant pSSRa-GATA4 $0.2 \mu \mathrm{g}$ of ANP(-2600)-Luc, and $0.04 \mu \mathrm{g}$ of pGL4.75 were used. The activity of the ANP promoter was presented as fold-activation of the firefly luciferase relative to the Renilla luciferase. Values are the mean \pm SD of data from three independent experiments performed in triplicate. ${ }^{* * * *}$ Both represent $\mathrm{P}<0.0001$, when compared with the wild-type GATA4.

The association of GATA4 variations with VSD in humans was first described in 1999. Pehlivan and colleagues (35) investigated patients with the 8p23 syndrome and found that GATA4 haploinsufficiency was responsible for congenital heart disease including VSD. Garg et al (18) identified the first two unrelated families with congenital heart defects caused by two GATA4 mutations, respectively, of which in family A, the pG296S mutation was detected in three patients with VSD in combination with atrial septal defects and pulmonary stenosis or patent ductus arteriosus. Functional assays of the pG296S mutation revealed a significantly impaired affinity to the promoter DNA and a failure of GATA4 to interact with TBX5 resulting in a significant decrease of target gene expression. Subsequently, the pG296S mutation of GATA4 was observed in another family with atrial septal defects, VSD and pulmonary valve stenosis, and in a third family with atrial septal defects, and pulmonary valve stenosis (36). Interestingly, the pG296C mutation of GATA4 was observed in a family with atrial septal defects and pulmonary stenosis (24). In the present study, the pG296R mutation of GATA4 was observed in a family with VSD, atrial septal defects and pulmonary stenosis. These results demonstrated that the glycine at amino acid position 296 of GATA4 is functionally important and a mutation hotspot for VSD, although a long list of GATA4 mutations linked to isolated or syndromic VSD have been reported, such as p.A6V (25), p.H28Y (27), p.S46del (25), p.A66T (27), p.A118_A119insA (25), p.A125_A126insAA (25), p.P163S (24), p.E216D (22), p.Q316E (23), p.E359K (25), p.P407Q (32), p.A411V (23), p.D425N (23), p.S429T (25), p.H436Y (27) and p.A442V (25).

To date, at least 20 germline mutations in the coding region of GATA4 have been identified in VSD patients with or without other concurrent cardiovascular defects, showing that although GATA4 mutations are involved in a great variety of congenital cardiac malformations, one of the most frequent phenotypes due to a mutation in GATA4 is VSD $(18,22-25,27,32,36,37)$. Nevertheless, the substantially varied prevalence of GATA4 mutations associated with congenital cardiovascular diseases was reported, which was roughly 0.0 (0/99), 0.5 (1/205), 0.8 (5/628), 0.8 (1/120), 1.0 (1/104), 1.4\% (5/357), 1.7 (2/120), 2.2 (3/135), 2.5 (12/486), 3.7 (4/107), 6.9 $(2 / 29), 10.0(5 / 50)$ or $12.5 \%(2 / 16)$, with a total prevalence of $1.8 \%(43 / 2456)$ based on these reports $(21-27,32,33,36-39)$. Similarly, a GATA4 mutation prevalence of nearly $0.5 \%$ $(1 / 210)$ was observed in our VSD population, implying that the GATA4 mutations could be a minor cause of congenital VSD. It was noteworthy that remarkable genetic heterogeneity of VSD was substantiated by an inability to find mutations in about $99.5 \%$ of our cohort patients, despite somatic GATA4 mutations as a potential mechanism of VSD in some patients $(20,40,41)$. Therefore, the contribution of genes other than GATA4 to VSD pathogenesis seems likely.

Mutations in other transcription factors associated with cardiogenesis, such as NKX2-5, GATA6 and TBX5, have also been identified in patients with VSD (42-47) and also mutations in cardiac structural proteins such as troponin I type 3 (TNNI3) and $\alpha$ myosin heavy chain (MYH6) were identified in VSD patients $(48,49)$. However, in the current study population, genetic analysis of NKX2-5 and GATA6 was performed as previously described $(43,45)$ and no novel mutations were observed, implying the importance of other genes in the pathogenesis of VSD.

Association of impaired GATA4 with increased susceptibility to VSD and other cardiac dysmorphias have been documented in animals. In the embryonic hearts of knockdown chicks generated by using small interfering RNAs targeted to GATA4, the bilateral myocardial rudiments failed 
to travel to the midline, resulting in the formation of two separate hearts in lateral positions, an anomaly of cardia bifida (50). In other studies, mice lacking both GATA4 alleles died between Days 7.0 to 9.5 of embryonic development because of abnormal embryogenesis and heart tube formation, including septal defects, right ventricular hypoplasia, endocardial cushion defect, tetralogy of Fallot, double outlets of the right ventricle, and cardiomyopathy (51-53). In a study of transgenic mice expressing a missense mutation in a highly conserved zinc-finger domain of GATA4 (p.V217G), the embryos died after embryonic Day 12.5 exhibiting features in common with congenital cardiovascular defects in humans (54). Additionally, GATA4 was also found to be indispensable for cardiogenesis in the fly, fish and Xenopus (55). Taken together, these experimental results from animals have clarified that GATA4 plays an important role in the morphogenesis and differentiation of the heart and compromised GATA4 may underlie a variety of congenital cardiac abnormalities including VSD in humans.

Previous studies have revealed that GATA4 is an upstream regulator or transcriptional activator of several genes expressed during cardiac development including the ANP gene, the brain natriuretic peptide gene, and the $\alpha$-cardiac actin gene (34). GATA4 binding to target DNA may occur in conjunction with other partners including the transcription factors TBX5 and NKX2-5, and the synergistic transcriptional activation mediated by TBX5 and NKX2-5 has been previously reported $(18,56,57)$. Therefore, the functional characteristics of the GATA4 mutations can be explored by analysis of the transcriptional activity of the ANP promoter in cells transfected with GATA4 mutants in contrast to wild-type. In this study, the functional role of the novel p.G296R mutation of GATA4 identified in our familial VSD patients was characterized by transcriptional activity assays and showed a significantly decreased transcriptional activity on a downstream gene, consistent with the loss-of function effects of other GATA4 mutations associated with cardiac septal defects on the transcriptional activity of the ANP promoter $(18,22,33)$. These findings indicate that haploinsufficiency or the dominant negative effects of GATA4 mutations are the major pathophysiological mechanisms involved in congenital VSD.

The finding of a novel GATA4 mutation in patients with congenital VSD contributes to making an early and precise diagnosis, which is clinically important, because leaving it uncorrected until adulthood may result in congestive heart failure and pulmonary hypertension, although some patients with minor VSD can often lead an otherwise healthy life. As the mortality rate of VSD operations is very low in patients without cardiac failure at an early age, timely surgical repair or catheter based closure of VSD is feasible. This information will be especially useful for genetic counseling of the family, because testing for p.G296R in new family members can be followed by careful medical examination and prophylactic intervention if VSD is found.

In conclusion, this study links a novel mutation in the cardiac transcription factor GATA4 to VSD and provides new insight into the molecular mechanism implicated in the pathogenesis of VSD, suggesting the potential implications for the genetic diagnosis and gene-specific therapy for this common disease in children.

\section{Acknowledgements}

We are indebted to participants for their dedication to the study. This study was supported in part by grants from the National Natural Science Fund of China (81070153, 30570768 and 30700776), the Natural Science Fund of Shanghai, China (10ZR1433100 and 10ZR1428000), the Key Program of Basic Research of Shanghai, China (10JC1414000, 10JC1414001 and 10JC1414002), the Personnel Development Fund of Shanghai (2010019), and the National Basic Research Program of China (2010CB912604).

\section{References}

1. Roger VL, Go AS, Lloyd-Jones DM, Adams RJ, Berry JD, Brown TM, Carnethon MR, Dai S, de Simone G, Ford ES, Fox CS, Fullerton HJ, Gillespie C, Greenlund KJ, Hailpern SM, Heit JA, Ho PM, Howard VJ, Kissela BM, Kittner SJ, Lackland DT, Lichtman JH, Lisabeth LD, Makuc DM, Marcus GM, Marelli A, Matchar DB, McDermott MM, Meigs JB, Moy CS, Mozaffarian D, Mussolino ME, Nichol G, Paynter NP, Rosamond WD, Sorlie PD, Stafford RS, Turan TN, Turner MB, Wong ND, Wylie-Rosett J; American Heart Association Statistics Committee and Stroke Statistics Subcommittee: Heart disease and stroke statistics-2011 update: a report from the American Heart Association. Circulation 119: e18-e209, 2011.

2. Minette MS and Sahn DJ: Ventricular septal defects. Circulation 114: 2190-2197, 2006.

3. Sommer RJ, Hijazi ZM and Rhodes JF Jr: Pathophysiology of congenital heart disease in the adult: part I: shunt lesions. Circulation 117: 1090-1099, 2008.

4. McQuillen PS and Miller SP: Congenital heart disease and brain development. Ann NY Acad Sci 1184: 68-86, 2010.

5. Walsh EP: Interventional electrophysiology in patients with congenital heart disease. Circulation 115: 3224-3234, 2007.

6. Walsh EP and Cecchin F: Arrhythmias in adult patients with congenital heart disease. Circulation 115: 534-545, 2007.

7. Yap SC and Harris L: Sudden cardiac death in adults with congenital heart disease. Expert Rev Cardiovasc Ther 7: 1605-1620, 2009.

8. Jenkins KJ, Correa A, Feinstein JA, Botto L, Britt AE, Daniels SR, Elixson M, Warnes CA, Webb CL; American Heart Association Council on Cardiovascular Disease in the Young: Noninherited risk factors and congenital cardiovascular defects: current knowledge: a scientific statement from the American Heart Association Council on Cardiovascular Disease in the Young: endorsed by the American Academy of Pediatrics. Circulation 115: 2995-3014, 2007.

9. Pierpont ME, Basson CT, Benson DW Jr, Gelb BD, Giglia TM, Goldmuntz E, McGee G, Sable CA, Srivastava D, Webb CL; American Heart Association Congenital Cardiac Defects Committee, Council on Cardiovascular Disease in the Young: Genetic basis for congenital heart defects: current knowledge: a scientific statement from the American Heart Association Congenital Cardiac Defects Committee, Council on Cardiovascular Disease in the Young: endorsed by the American Academy of Pediatrics. Circulation 115: 3015-3038, 2007.

10. Pemberton VL, McCrindle BW, Barkin S, Daniels SR, Barlow SE, Binns HJ, Cohen MS, Economos C, Faith MS, Gidding SS, Goldberg CS, Kavey RE, Longmuir P, Rocchini AP, Van Horn L and Kaltman JR: Report of the National Heart, Lung, and Blood Institute's Working Group on obesity and other cardiovascular risk factors in congenital heart disease. Circulation 121: 1153-1159, 2010.

11. White RA, Dowler LL, Pasztor LM, Gatson LL, Adkison LR, Angeloni SV and Wilson DB: Assignment of the transcription factor GATA4 gene to human chromosome 8 and mouse chromosome 14: Gata4 is a candidate gene for Ds (disorganization). Genomics 27: 20-26, 1995.

12. Pu WT, Ishiwata T, Juraszek AL, Ma Q and Izumo S: GATA4 is a dosage-sensitive regulator of cardiac morphogenesis. Dev Biol 275: 235-244, 2004.

13. Zeisberg EM, Ma Q, Juraszek AL, Moses K, Schwartz RJ, Izumo S and Pu WT: Morphogenesis of the right ventricle requires myocardial expression of Gata4. J Clin Invest 115: 1522-1531, 2005. 
14. Xin M, Davis CA, Molkentin JD, Lien CL, Duncan SA Richardson JA and Olson EN: A threshold of GATA4 and GATA6 expression is required for cardiovascular development. Proc Natl Acad Sci USA 103: 11189-11194, 2006.

15. Rivera-Feliciano J, Lee KH, Kong SW, Rajagopal S, Ma Q, Springer Z, Izumo S, Tabin CJ and Pu WT: Development of heart valves requires Gata4 expression in endothelial-derived cells. Development 133: 3607-3618, 2006.

16. Maitra M, Schluterman MK, Nichols HA, Richardson JA Lo CW, Srivastava D and Garg V: Interaction of Gata4 and Gata6 with Tbx5 is critical for normal cardiac development. Dev Biol 326: 368-377, 2009.

17. Moskowitz IP, Wang J, Peterson MA, Pu WT, Mackinnon AC, Oxburgh L, Chu GC, Sarkar M, Berul C, Smoot L, Robertson EJ, Schwartz R, Seidman JG and Seidman CE: Cardiac-specific transcription factor genes Smad4 and Gata4 cooperatively regulate cardiac valve development. Proc Natl Acad Sci USA 108: 4006-4011, 2011.

18. Garg V, Kathiriya IS, Barnes R, Schluterman MK, King IN Butler CA, Rothrock CR, Eapen RS, Hirayama-Yamada K, Joo K, Matsuoka R, Cohen JC and Srivastava D: GATA4 mutations cause human congenital heart defects and reveal an interaction with TBX5. Nature 424: 443-447, 2003.

19. Okubo A, Miyoshi O, Baba K, Takagi M, Tsukamoto K, Kinoshita A, Yoshiura K, Kishino T, Ohta T, Niikawa N and Matsumoto N: A novel GATA4 mutation completely segregated with atrial septal defect in a large Japanese family. J Med Genet 41: e97, 2004.

20. Reamon-Buettner SM and Borlak J: GATA4 zinc finger mutations as a molecular rationale for septation defects of the human heart. J Med Genet 42: e32, 2005.

21. Hirayama-Yamada K, Kamisago M, Akimoto K, Aotsuka H, Nakamura Y, Tomita H, Furutani M, Imamura S, Takao A, Nakazawa M and Matsuoka R: Phenotypes with GATA4 or NKX2.5 mutations in familial atrial septal defect. Am J Med Genet A 135: 47-52, 2005.

22. Nemer G, Fadlalah F, Usta J, Nemer M, Dbaibo G, Obeid M and Bitar F: A novel mutation in the GATA4 gene in patients with Tetralogy of Fallot. Hum Mutat 27: 293-294, 2006

23. Tomita-Mitchell A, Maslen CL, Morris CD, Garg V and Goldmuntz E: GATA4 sequence variants in patients with congenital heart disease. J Med Genet 44: 779-783, 2007.

24. Rajagopal SK, Ma Q, Obler D, Shen J, Manichaikul A, TomitaMitchell A, Boardman K, Briggs C, Garg V, Srivastava D, Goldmuntz E, Broman KW, Benson DW, Smoot LB and $\mathrm{Pu}$ WT: Spectrum of heart disease associated with murine and human GATA4 mutation. J Mol Cell Cardiol 43: 677-685, 2007.

25. Zhang W, Li X, Shen A, Jiao W, Guan X and Li Z: GATA4 mutations in 486 Chinese patients with congenital heart disease. Eur J Med Genet 51: 527-535, 2008.

26. Hamanoue H, Rahayuningsih SE, Hirahara Y, Itoh J, Yokoyama U, Mizuguchi T, Saitsu H, Miyake N, Hirahara F and Matsumoto N: Genetic screening of 104 patients with congenitally malformed hearts revealed a fresh mutation of GATA4 in those with atrial septal defects. Cardiol Young 19: 482-485, 2009.

27. Chen MW, Pang YS, Guo Y, Pan JH, Liu BL, Shen J and Liu TW: GATA4 mutations in Chinese patients with congenital cardiac septal defects. Pediatr Cardiol 31: 85-89, 2010.

28. Chen Y, Han ZQ, Yan WD, Tang CZ, Xie JY, Chen H and Hu DY: A novel mutation in GATA4 gene associated with dominant inherited familial atrial septal defect. J Thorac Cardiovasc Surg 140: 684-687, 2010

29. Chen Y, Mao J, Sun Y, Zhang Q, Cheng HB, Yan WH, Choy KW and $\mathrm{Li} \mathrm{H}$ : A novel mutation of GATA4 in a familial atrial septal defect. Clin Chim Acta 411: 1741-1745, 2010.

30. D'Amato E, Giacopelli F, Giannattasio A, D'Annunzio G, Bocciardi R, Musso M, Lorini R and Ravazzolo R: Genetic investigation in an Italian child with an unusual association of atrial septal defect, attributable to a new familial GATA4 gene mutation, and neonatal diabetes due to pancreatic agenesis Diabet Med 27: 1195-1200, 2010.

31. Posch MG, Perrot A, Berger F and Ozcelik C: Molecular genetics of congenital atrial septal defects. Clin Res Cardiol 99: 137-147, 2010.

32. Peng T, Wang L, Zhou SF and Li X: Mutations of the GATA4 and NKX2.5 genes in Chinese pediatric patients with nonfamilial congenital heart disease. Genetica 138: 1231-1240, 2010
33. Liu XY, Wang J, Zheng JH, Bai K, Liu ZM, Wang XZ, Liu X, Fang WY and Yang YQ: Involvement of a novel GATA4 mutation in atrial septal defects. Int J Mol Med 28: 17-23, 2011.

34. Brewer A and Pizzey J: GATA factors in vertebrate heart development and disease. Expert Rev Mol Med 8: 1-20, 2006.

35. Pehlivan T, Pober BR, Brueckner M, Garrett S, Slaugh R, Van Rheeden R, Wilson DB, Watson MS and Hing AV: GATA4 haploinsufficiency in patients with interstitial deletion of chromosome region 8p23.1 and congenital heart disease. Am J Med Genet 83: 201-206, 1999.

36. Sarkozy A, Conti E, Neri C, D'Agostino R, Digilio MC, Esposito G, Toscano A, Marino B, Pizzuti A and Dallapiccola B: Spectrum of atrial septal defects associated with mutations of NKX2.5 and GATA4 transcription factors. J Med Genet 42: e16, 2005.

37. Posch MG, Perrot A, Schmitt K, Mittelhaus S, Esenwein EM Stiller B, Geier C, Dietz R, Gessner R, Ozcelik C and Berger F: Mutations in GATA4, NKX2.5, CRELD1, and BMP4 are infrequently found in patients with congenital cardiac septal defects. Am J Med Genet A 146A: 251-253, 2008

38. Zhang L, Tümer Z, Jacobsen JR, Andersen PS, Tommerup N and Larsen LA: Screening of 99 Danish patients with congenital heart disease for GATA4 mutations. Genet Test 10: 277-280, 2006.

39. Butler TL, Esposito G, Blue GM, Cole AD, Costa MW, Waddell LB, Walizada G, Sholler GF, Kirk EP, Feneley M, Harvey RP and Winlaw DS: GATA4 mutations in 357 unrelated patients with congenital heart malformation. Genet Test Mol Biomarkers 14: 797-802, 2010.

40. Reamon-Buettner SM, Cho SH and Borlak J: Mutations in the 3'-untranslated region of GATA4 as molecular hotspots for congenital heart disease (CHD). BMC Med Genet 8: 38, 2007.

41. Salazar M, Consoli F, Villegas V, Caicedo V, Maddaloni V, Daniele P, Caianiello G, Pachón S, Nuñez F, Limongelli G, Pacileo G, Marino B, Bernal JE, De Luca A and Dallapiccola B: Search of somatic GATA4 and NKX2.5 gene mutations in sporadic septal heart defects. Eur J Med Genet 54: 306-309, 2011.

42. Schott JJ, Benson DW, Basson CT, Pease W, Silberbach GM, Moak JP, Maron BJ, Seidman CE and Seidman JG: Congenital heart disease caused by mutations in the transcription factor NKX2-5. Science 281: 108-111, 1998.

43. Wang J, Xin YF, Liu XY, Liu ZM, Wang XZ and Yang YQ: A novel NKX2-5 mutation in familial ventricular septal defect. Int J Mol Med 27: 369-375, 2011.

44. Maitra M, Koenig SN, Srivastava D and Garg V: Identification of GATA6 sequence variants in patients with congenital heart defects. Pediatr Res 68: 281-285, 2010.

45. Lin X, Huo Z, Liu X, Zhang Y, Li L, Zhao H, Yan B, Liu Y, Yang Y and Chen YH: A novel GATA6 mutation in patients with tetralogy of Fallot or atrial septal defect. J Hum Genet 55: 662-667, 2010.

46. Li QY, Newbury-Ecob RA, Terrett JA, Wilson DI, Curtis AR, Yi CH, Gebuhr T, Bullen PJ, Robson SC, Strachan T, Bonnet D, Lyonnet S, Young ID, Raeburn JA, Buckler AJ, Law DJ and Brook JD: Holt-Oram syndrome is caused by mutations in TBX5, a member of the Brachyury (T) gene family. Nat Genet 15: 21-29, 1997

47. Basson CT, Bachinsky DR, Lin RC, Levi T, Elkins JA, Soults J, Grayzel D, Kroumpouzou E, Traill TA, Leblanc-Straceski J, Renault B, Kucherlapati R, Seidman JG and Seidman CE: Mutations in human TBX5 cause limb and cardiac malformation in Holt-Oram syndrome. Nat Genet 15: 30-35, 1997.

48. Yang SW, Hitz MP and Andelfinger G: Ventricular septal defect and restrictive cardiomyopathy in a paediatric TNNI3 mutation carrier. Cardiol Young 20: 574-576, 2010.

49. Granados-Riveron JT, Ghosh TK, Pope M, Bu'Lock F, Thornborough C, Eason J, Kirk EP, Fatkin D, Feneley MP, Harvey RP, Armour JA and David Brook J: Alpha-cardiac myosin heavy chain (MYH6) mutations affecting myofibril formation are associated with congenital heart defects. Hum Mol Genet 19: 4007-4016, 2010.

50. Zhang H, Toyofuku T, Kamei J and Hori M: GATA-4 regulates cardiac morphogenesis through transactivation of the N-cadherin gene. Biochem Biophys Res Commun 312: $1033-1038,2003$.

51. Kuo CT, Morrisey EE, Anandappa R, Sigrist K, Lu MM, Parmacek MS, Soudais C and Leiden JM: GATA4 transcription factor is required for ventral morphogenesis and heart tube formation. Genes Dev 11: 1048-1060, 1997. 
52. Molkentin JD, Lin Q, Duncan SA and Olson EN: Requirement of the transcription factor GATA4 for heart tube formation and ventral morphogenesis. Genes Dev 11: 1061-1072, 1997.

53. Watt AJ, Battle MA, Li J and Duncan SA: GATA4 is essential for formation of the proepicardium and regulates cardiogenesis. Proc Natl Acad Sci USA 101: 12573-12578, 2004.

54. Crispino JD, Lodish MB, Thurberg BL, Litovsky SH, Collins T, Molkentin JD and Orkin SH: Proper coronary vascular development and heart morphogenesis depend on interaction of GATA-4 with FOG cofactors. Genes Dev 15: 839-844, 2001.

55. Epstein JA and Parmacek MS: Recent advances in cardiac development with therapeutic implications for adult cardiovascular disease. Circulation 112: 592-597, 2005.
56. Lee Y, Shioi T, Kasahara H, Jobe SM, Wiese RJ, Markham BE and Izumo S: The cardiac tissue-restricted homeobox protein Csx/Nkx2-5 physically associates with the zinc finger protein GATA4 and cooperatively activates atrial natriuretic factor gene expression. Mol Cell Biol 18: 3120-3129, 1998.

57. Shiojima I, Komuro I, Oka T, Hiroi Y, Mizuno T, Takimoto E, Monzen K, Aikawa R, Akazawa H, Yamazaki T, Kudoh S and Yazaki Y: Context-dependent transcriptional cooperation mediated by cardiac transcription factors $\mathrm{Csx} / \mathrm{Nkx} 2.5$ and GATA-4. J Biol Chem 274: 8231-8239, 1999. 